\title{
PENINGKATAN EFISIENSI MESIN CNC TURNING MENGGUNAKAN METODE SINGLE MINUTES EXCHANGE OF DIES DI PT.X
}

\author{
Muhammad Faizal Nurrizky ${ }^{1}$, Muhammad Anwar Septiana ${ }^{2}$, Jamari Machmudin $^{3}$, Muhamad Syafii ${ }^{4}$ \\ Program Studi Teknik Industri 1, 2, 3 \\ Universitas Widyatama \\ Jl. Cikutra Bandung \\ faizal.nurrizky@widyatama.ac.id ${ }^{\mathbf{1}}$, anwar.septiana@widyatama.ac.id ${ }^{2}$,jamarimachmudin10@gmail.com², \\ muhamad.syafii@widyatama.ac.id ${ }^{4}$
}

\begin{abstract}
Abstrak
Perusahaan $\mathrm{X}$ adalah sebuah perusahaan yang bergerak dibidang manufaktur yang memproduksi produk Sparepart Aerospace menggunakan mesin produksi CNC. Kendala yang dihadapi Perushaan X adalah waktu set-up yang lama dan berulang-ulang, Penelitian ini bertujuan untuk meminimasi waktu setup agar dapat meningkatkan produktivitas produksi dengan mengunakan Metode Single Minute Exchange Die (SMED) pada perusahaan X. Tahapan yang dilakukan antara lain langkah pengumpulan data elemen gerakan set-up yang dilakukan, memisahkan internal set-up menjadi ekternal set-up, menyederhanakan seluruh aspek operasi set-up serta perhitungan produktifitas dari penerapan SMED. Mesin CNC di Perusahaan $\mathrm{X}$ berjumlah 8 mesin dimana tingkat efisiensi mesin hanya mencapai 50\% $75 \%$. Berdasarkan data produksi perusahaan bahwa kontribusi pada aktivitas set-up merupakan pengaruh terbesar terhadap waktu menganggur mesin CNC yaitu mencapai 55\% dengan waktu set-up selama 51,05 menit pada tiap 1 kali set-up. Perbedaan pada tiap operator menjadi permasalahan dalam perusahaan $X$. Perhitungan waktu set-up dengan menggunakan metode (SMED) diperoleh waktu set-up sebesar 44,3 menit, waktu set-up sebesar 51,05 menit terdapat penurunan waktu set-up sebesar 6,75 menit
\end{abstract}

Kata kunci :

Single Minute Exchange of Dies, SMED, CNC, Waktu set-up

Abstract
$\begin{gathered}\text { Company } \mathrm{X} \text { is a company engaged in } \\ \text { manufacturing that produces Aerospace Spare Parts }\end{gathered}$

products using $\mathrm{CNC}$ production machines. The obstacle faced by Enterprise $\mathrm{X}$ is the set-up time that is long and repetitive, this study aims to minimize setup time in order to increase production productivity by using the Single Minute Exchange Die (SMED) method in company X. Stages conducted including steps to collect the set-up motion elements performed, separate the internal set-up into an external set-up, simplify all aspects of the set-up operation and calculate the productivity of the implementation of SMED. CNC machines in Company $\mathrm{X}$ number 8 machines where the level of machine efficiency reaches only $50 \%-75 \%$. Based on the company's production data that the contribution to the set-up activity is the biggest influence on the idle time of the $\mathrm{CNC}$ machine that reaches $55 \%$ with a set-up time of 51,05 minutes at every 1 set-up. The model set-up that is different for each operator becomes a problem in company X. Calculation of set-up time using the (SMED) method is obtained by the set-up time amounted to 44.3 minutes, method by 51.05 minutes there was a decrease in set-up time of 6,75 minutes

Keywords :

Single Minute Exchange of Dies, SMED, CNC, setup time

\section{Pendahuluan}

Salah satu kendala besar pada perusahaan manufaktur adalah variasi produk yang tinggi sehingga sering terjadi aktivitas pergantian tools, fixture dan persiapan benda kerja lainnya. Suatu perusahaan tidak meningkatkan kecepatan pelayanannya, maka perusahaan tersebut tidak dapat bersaing dengan perusahaan yang lain, Karena konsumen akan lebih memilih perusahaan yang

Muhammad Faizal Nurrizky, Muhammad Anwar Septiana, Jamari Machmudin, Muhamad Syafii

Jurnal Ilmiah Teknologi Informasi Terapan

Volume 7, No 2, 15 April 2021 
memberikan pelayanan dengan cepat. Meningkatkan kecepatan pelayanan terhadap konsumen, perusahaan harus mengkaji beberapa faktor yang mempengaruhi produktivitas perusahaan. Faktor-faktor yang mempengaruhi antara lain adalah waktu set-up, waktu proses, kondisi mesin dan lain-lain. Waktu set-up dan waktu proses sangat mempengaruhi waktu siklus pembuatan suatu produk.

Perusahaan $\mathrm{X}$ adalah sebuah perusahaan yang bergerak dibidang manufaktur yang memproduksi Sparepart Aerospace menggunakan mesin produksi $C N C$. Keadaan proses produksi di Perusahaan $\mathrm{X}$ saat ini adalah rendahnya tingkat efisiensi pada mesin $C N C$. Mesin $C N C$ di Perusahaan $\mathrm{X}$ berjumlah 8 mesin dimana tingkat efisiensi mesin hanya mencapai $50 \%$ $75 \%$. Minimnya efisiensi mesin $C N C$ ini di akibatkan karena tingginya waktu menganggur pada mesin $C N C$ tersebut yaitu mencapai $25 \%-45 \%$ dengan waktu menganggur rata-rata 128 menit terhadap jam kerja yang tersedia tiap harinya. Berdasarkan data produksi perusahaan bahwa kontribusi pada aktivitas set-up merupakan pengaruh terbesar terhadap waktu menganggur mesin $C N C$ yaitu mencapai $55 \%$ dengan waktu set-up selama 70 menit pada tiap 1 kali set-up. Selain itu, jarak antar stasiun kerja ketika set-up dan model set-up yang berbeda-beda pada tiap operator menjadi faktor lain permasalahan dalam perusahaan $\mathrm{X}$.

Menurut Ohno, T. (1998), pemborosan adalah segala sesuatu yang tidak memberikan nilai tambah (non-value added) antara lain pemrosesan berlebih, pemindahan, penantian, inventaris, cacat, dan pengangkutan. Hal-hal yang dilakukan dalam proses pergantian model adalah menghilangkan gerakan yang tidak perlu dalam proses pergantian, menunggu, dan menyesuaikan pengaturan internal dan pengaturan eksternal.

Pada kasus yang terdapat pada perushaan $\mathrm{X}$ masalah yang terjadi adalah waktu set-up yang lama dan berulang-ulang untuk setiap pembuatan sparepart, kegiatan set-up dalam satu shift rata-rata dilakukan sebanyak 2 - 3 kali set-up sehingga berpengaruh besar terhadap waktu total penyelesaian produk dan jumlah produk yang dihasilkan oleh perusahaan. Salah satu cara yang dapat dilakukan Perusahaan X untuk mengatasi masalah tersebut adalah dengan meminimasi waktu set-up mesin CNC agar dapat mempercepat penyelesaian produk. Mengatasi permasalahan tersebut dibutuhkan suatu metode yaitu Single Minute Exchange of die (SMED).
Metode SMED adalah salah satu metode dari Lean Manufacturing yang digunakan untuk mempercepat waktu yang dibutuhkan untuk melakukan set-up pergantian dari memproduksi satu jenis produk ke model produk lainnya. Manfaat dari metode ini adalah untuk meminimasi waktu set-up dan meningkatkan produktivitas dari perusahaan.

\section{KAJIAN LITERATUR}

Menurut Shongo (1985), definisi sistem SMED adalah sistem atau metode yang merupakan serangkaian teknik yang memungkinkan untuk melakukan set-up atau changeover kurang dari 10 menit. Kata "single minute" bukan berarti bahwa lama waktu set-up hanya membutuhkan waktu satu menit, tapi membutuhkan waktu di bawah 10 menit (dengan kata lain "single digit minute"). Menurut Goubergent and Sherali (2004), filosofi kunci dibalik metode $S M E D$ adalah adanya dua aktifitas set-up yang merupakan dasar dari metode SMED yaitu, internal set-up hanya dilakukan bila mesin dalam kondisi shutdown dan external set-up dapat dilakukan pada saat mesin dalam keadaan operasi. Kedua konsep tersebut merupakan konsep yang sangat penting dalam implementasi $S M E D$.

Lean Manudacturing adalah pendekatan sistematis yang digunakan untuk mengidentifikasi dan menghilangkan pemborosan melalui aktivitas berkelanjutan. Menurut Arief (2017), Studi tentang bagaimana meningkatkan waktu persiapan dan mengurangi waktu tunggu telah dilaksanakan, antara lain dengan menggunakan metode SMED dan Pekerjaan yang terstandardisasi. Dalam menerapkan lean manufacturing, metode ini tidak hanya akan berdiri sendiri tetapi juga bersinergi dengan metode lain di lean manufacturing lainnya.

Shongo (1985), mengembangkan sebuah metodologi untuk menganalisa dan mengurangi waktu changeover yang disebut dengan sistem SMED, menurut Suhardi.B \& Satwikaningrum.D (2015) tahapan implementasinya digambarkan sebagai berikut:

1. Tahap: Pendahuluan atau persiapan (preliminary)

Melakukan analis kondisi sistem produksi, seperti menganalisis proses produksi secara berkesinambungan dengan menggunakan stopwatch dan sampling pekerjaan, melakukan wawancara dengan pekerja,serta

Muhammad Faizal Nurrizky, Muhammad Anwar Septiana, Jamari Machmudin, Muhamad Syafii 
melakukan pengambilan data elemen kerja yang dilakukan oleh operator

2. Tahap: pemisahan internal dan eksternal setup (separating internal set-up and external set-up).

Internal set-up merupakan proses set-up pada saat mesin beroperasi, sedangkan eksternal set-up merupakan proses set-up saat mesin sedang berhenti beroperasi.

3. Tahap: mengubah internal set-up menjadi eksternal set-up (converting internal set-up to external set-up).

Mengubah internal set-up menjadi eksternal set-up sebagai dengan cara melakukan langkah pemeriksaan kembali pada setiap operasi untuk melihat apakah ada langkah yang salah sehingga diasumsikan sebagai internal set-up kemudian temukan cara untuk mengubah langkah tersebut menjadi eksternal set-up

4. Tahap: pengurangan atau perampingan semua aspek operasi set-up (streamlining all aspects of the set-up operation)

Perampingan semua aspek operasi, dilakukan perbaikan internal set-up dengan tujuan untuk meminimalkan waktu set-up internal sehingga waktu berhenti mesin dapat dikurangi

Menurut Adanna, I. W., dan Shantharam, A. (2014), penerapan metode SMED telah terbukti mengurangi waktu set-up date di berbagai industri. Penerapan SMED pada proses set-up dapat menghemat 58,3 persen waktu untuk axle grinder sehingga produktivitas meningkat. Kemudian menurut Sivakumar, M., Balasubramani, T., \& Stany , M. C. (2015), penerapan SMED pada Carriage Building Press, hasilnya kami dapat mengurangi perubahan seiring waktu sebesar 44,16 persen dari 98 menit menjadi 60 menit. Manfaat penerapan metode Single Minute Exchange of Dies (SMED) menurut Saputra, R., dkk (2016) adalah sebagai berikut:

1. Mengurangi waktu penyiapan (dari beberapa hari menjadi beberapa menit)

2. Kurangi lead time produksi
3. Pengurangan hambatan (WIP turun hingga $90 \%)$ )

4. Mengurangi biaya produksi

5. Meningkatkan kualitas produk yang dihasilkan

Penelitian ini akan dilaksanakan di divisi kerja CNC Turning Machining, departemen produski Cell A+B Perusahaan X. Perusahaan tersebut berlokasi di Gedebage Kota Bandung. Divisi CNC Turning Machining merupakan divisi yang melakukan produksi sparepart aerospace.

Dalam penelitian ini jenis data terdiri dari data sekunder dan data primer. Data sekunder didapatkan berdasarkan sumber-sumber yang terpercaya sedangkan data primer didapatkan langsung dari hasil observasi yang dilakukan. Berikut ini adalah jenis data dari penelitian yang dilakukan:

1. Data Sekunder

Data sekunder merupakan data penelitian yang diperoleh tidak secara langsung, yaitu data yang dapat diperoleh dari berbagai macam sumber seperti studi kepustakaan, jurnal, buku hingga artikel ilmiah lainnya yang berkaitan. Selain itu digunakan data dari Perusahaan $\mathrm{X}$ untuk menunjang penelitian ini.

2. Data Primer

Data primer adalah sumber data penelitian yang diperoleh secara langsung dari sumber aslinya yang berupa wawancara, jajak pendapat dari individu atau kelompok (orang) maupun hasil observasi dari suatu obyek, kejadian atau hasil pengujian.

Metode pengumpulan data pada penelitian ini menggunakan beberapa metode yaitu sebagai berikut:

1. Observasi

Observasi dilakukan dengan melakukan pengamatan secara langsung terhadap obyek yang di teliti, yaitu melakukan pengamatan, perekaman, dan melakukan studi waktu untuk waktu set-up setting pergantian tool di mesin CNC Turning dan pergantian benda kerja di mesin CNC Turning.

2. Wawancara

Wawancara merupakan metode yang digunakan untuk mengumpulkan informasi ataupun data secara langsung, dengan

Muhammad Faizal Nurrizky, Muhammad Anwar Septiana, Jamari Machmudin, Muhamad Syafii 
melakukan tanya jawab secara langsung kepada foreman, kepala bagian, leader, setter dan operator di divisi CNC Turning Machining.

3. Tinjauan Pustaka

Tinjauan Pustaka merupakan bentuk penelitian yang dilakukan dengan membaca literatur-literatur, karangan ilmiah serta berbagai bahan pustaka lainnya yang ada hubungannya dengan penulisan penelitian ini

\section{METODOLOGI PENELITIAN}

Metode yang digunakan untuk mengurangi waktu aktivasi dalam proses set-up mesin $C N C$ di PT. X adalah Single Minutes Exchange Of Dies (SMED). Data lama waktu set-up awal mesin $C N C$ digunakan untuk dianalisa dan diolah menggunakan metode ini. Berikut flowchart penelitian yang dilakukan:

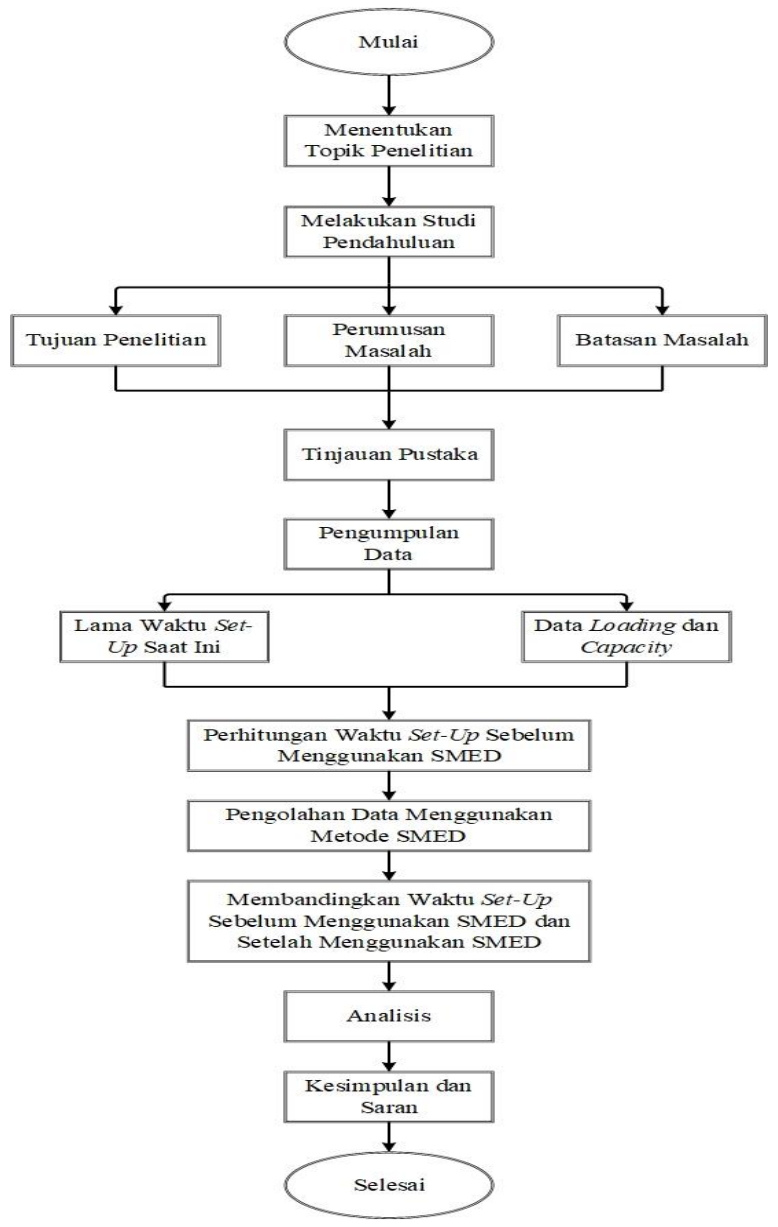

Gambar 1. Diagram Alur Penelitian

\section{Analisis dan Perancangan}

Pengamatan dilakukan pada proses pemesinan mesin CNC Turning yang memproduksi sparepart aerospace. Agar mencapai hasil perbaikan waktu setup dengan Langkah-langkah metode Single Minute Exchange Die (SMED). Aktivitas set-up awal yang dilakukan pada mesin CNC Turning sebelum menggunakan metode $S M E D$ dapat dilihat pada tabel 1

Tabel 1. Waktu Aktivasi Awal Set-up Mesin CNC

\begin{tabular}{|c|c|c|}
\hline No & Aktivasi Awal & $\begin{array}{l}\text { Waktu } \\
\text { (menit) }\end{array}$ \\
\hline 1 & $\begin{array}{l}\text { Running Proses } 1 \text { part terakhir dari lot } \\
\text { berjalan }\end{array}$ & 3,000 \\
\hline 2 & Proses Berhenti & 0,083 \\
\hline 3 & Pergi menuju kamar alat & 1,333 \\
\hline 4 & $\begin{array}{l}\text { Mengambil tools insert, bor, cut off di } \\
\text { kamar alat }\end{array}$ & 0,433 \\
\hline 5 & Pergi menuju mesin untuk set-up mesin & 1,333 \\
\hline 6 & $\begin{array}{l}\text { Menaruh tools insert, bor, cut off pada } \\
\text { meja kerja }\end{array}$ & 0,083 \\
\hline 7 & Pergi menuju ruangan fixture & 1,167 \\
\hline 8 & Mengambil fixture di ruangan fixture & 0.417 \\
\hline 9 & Pergi menuju mesin untuk set-up mesin & 1,167 \\
\hline 10 & Menaruh fixture pada meja kerja & 0,083 \\
\hline 11 & $\begin{array}{l}\text { Mengambil tools kunci L, kunci pas, pipa } \\
\text { di lemari tools }\end{array}$ & 0,417 \\
\hline 12 & $\begin{array}{l}\text { Bongkar fixture yang masih terpasang di } \\
\text { mesin }\end{array}$ & 4,167 \\
\hline 13 & Menarut fixture dan tools pada meja kerja & 0,483 \\
\hline 14 & Mengambil tools dan fixture yang baru & 0,483 \\
\hline 15 & Memasang fixture yang baru pada mesin & 5,100 \\
\hline 16 & Pergi menuju ruangan fixture & 1,167 \\
\hline 17 & $\begin{array}{l}\text { Menaruh dan mengembalikan fixture } \\
\text { yang lama }\end{array}$ & 0,417 \\
\hline 18 & Pergi menuju mesin untuk set-up mesin & 1,167 \\
\hline 19 & $\begin{array}{l}\text { Mengambil tools kunci L, kunci Sci di } \\
\text { lemari tools }\end{array}$ & 0,550 \\
\hline 20 & $\begin{array}{l}\text { Memasang tools insert, bor, cut off pada } \\
\text { toolpost mesin }\end{array}$ & 7,500 \\
\hline 21 & $\begin{array}{l}\text { Menyimpan seluruh tools di meja ke } \\
\text { lemari tools }\end{array}$ & 0,500 \\
\hline 22 & Memasukan Program CNC pada mesin & 3,333 \\
\hline 23 & $\begin{array}{l}\text { Mengambil dan measangn bahan benda } \\
\text { kerja pada } \text { chuck mesin }\end{array}$ & 1,200 \\
\hline 24 & Setting 0 insert tools pada benda kerja & 7,250 \\
\hline 25 & Proses running trial part & 3,333 \\
\hline 26 & Ambil part trial pada chuck mesin & 0,350 \\
\hline 27 & $\begin{array}{l}\text { Ukur dimensi Part Trial menggunakan } \\
\text { gauge dan micrometer }\end{array}$ & 0,500 \\
\hline 28 & Setting offset insert tools pada mesin & 0,700 \\
\hline \multirow[t]{2}{*}{29} & $\begin{array}{l}\text { Proses running part pertama lot } \\
\text { selanjutnya }\end{array}$ & 3,333 \\
\hline & Total & 51,05 \\
\hline
\end{tabular}

(Sumber : Pengolahan Data)

Berdasarkan Tabel 1 diatas total waktu yang dibutuhkan untuk aktivitas Set-up awal memerlukan

Muhammad Faizal Nurrizky, Muhammad Anwar Septiana, Jamari Machmudin, Muhamad Syafii Jurnal Ilmiah Teknologi Informasi Terapan Volume 7, No 2, 15 April 2021 
waktu 51,050 menit untuk set-up mesin $C N C$ yang memproduksi part aerospace, dengan waktu mencapai 51,050 menit hal ini menjadikan waktu setup mesin $C N C$ cenderung besar, sehingga untuk meminimasi aktivitas set-up mesin dianjurkan untuk menggunakan metode SMED, dikarenakan seluruh kegiatan set-up awal dilakukan dengan internal set-up (kegiatan set-up dilakukan pada saat mesin berhenti) mengakibatkan waktu set-up semakin lama, dikarenakan operator mesin harus menunggu seluruh proses operasi yang berbeda pada mesin $C N C$ tersebut selesai, setelah selesai itu baru dapat dilakukan set-up untuk mesin $C N C$ tersebut.

Selanjutnya setelah dilakukan perbaikan dari setup mesin maka selanjutnya terdapat beberapa aktivitas yang digabungkan, dikurangi dan dipindahkan urutannya. Aktivitas set-up setelah dilakukan improvement yang dilakukan pada mesin CNC Turning dapat dilihat pada Tabel 2

Tabel 1. Waktu Aktivasi Set-up Mesin CNC Setelah Perbaikan

\begin{tabular}{|c|c|c|c|c|}
\hline No & $\begin{array}{c}\text { Aktivitas } \\
\text { Awal }\end{array}$ & $\begin{array}{l}\text { Waktu } \\
\text { (menit) }\end{array}$ & $\begin{array}{c}\text { Internal } \\
\text { Set-Up }\end{array}$ & $\begin{array}{l}\text { External } \\
\text { Set-Up }\end{array}$ \\
\hline 1 & $\begin{array}{l}\text { Running Proses } 2 \\
\text { part terakhir dari } \\
\text { lot berjalan }\end{array}$ & 6,000 & & \\
\hline 2 & $\begin{array}{l}\text { Pergi menuju } \\
\text { kamar alat }\end{array}$ & 1,333 & & \\
\hline 3 & $\begin{array}{l}\text { Mengambil tools } \\
\text { insert, bor, cut off } \\
\text { di kamar alat }\end{array}$ & 0,433 & & \\
\hline 4 & $\begin{array}{l}\text { Pergi menuju } \\
\text { ruangan fixture }\end{array}$ & 1,167 & & \\
\hline 5 & $\begin{array}{l}\text { Mengambil } \\
\text { fixture di ruangan } \\
\text { fixture }\end{array}$ & 0,417 & & \\
\hline 6 & $\begin{array}{l}\text { Pergi menuju } \\
\text { mesin untuk setuo } \\
\text { mesin }\end{array}$ & 1,167 & & \\
\hline 7 & $\begin{array}{l}\text { Menaruh fixture } \\
\text { dan tools insert, } \\
\text { bor, cut off pada } \\
\text { meja kerja }\end{array}$ & 0,083 & & \\
\hline 8 & $\begin{array}{l}\text { Proses lot berjalan } \\
\text { berhenti }\end{array}$ & 0,083 & & \\
\hline 9 & $\begin{array}{l}\text { Mengambil tools } \\
\text { kunci L, kunci } \\
\text { pas, pipa di lemari } \\
\text { tools }\end{array}$ & 0,417 & & \\
\hline 10 & $\begin{array}{lr}\text { Bongkar } & \text { ficture } \\
\text { yang } & \text { masih } \\
\text { terpasang } & \text { di } \\
\text { mesin } & \end{array}$ & 4,167 & & \\
\hline 11 & $\begin{array}{l}\text { Menaruh fixture } \\
\text { yang lama dan }\end{array}$ & 0,483 & & \\
\hline
\end{tabular}

tools pada meja kerja

12 Memasang fixture yang baru pada mesin

13 Mengambil tools kunci L, kunci Sci dilemari tools

14 Memasang tools insert, bor, cut off pada toolpost mesin

15 Memasukan Program $\quad \mathrm{CNC}$ pada mesin

16 Mengambil dan memasang bahan benda kerja pada chuck mesin

17 Setting 0 (zero) insert tools pada benda kerja

18 Proses running trial part

19 Ambil Part Trial pada chuck mesin

20 Ukur dimensi Part Trial menggunakan gauge dan micrometer

21 Setting offset insert tools pada mesin

22 Proses running Part Product Pertama

23 Menyimpan seluruh tools dimeja ke lemari tools

24 Pergi mепији 1,167 ruangan fixture

25 Menaruh Mengembalikan fixture yang lama Total

5,100

0,550

7,500

3,300

1,200

7,250

3,333

0,350

0,500

0,700

3,333

0,500

50,983

44,300

6,683

(Sumber : Pengolahan Data)

Berdasarkan Tabel 2 diatas dilakukan penggabungan saat mengambil tools inset,bor,cut off di kamar alat dan selanjutnya langsung mengunjungi ruangan fixture untuk mengambil fixture yang akan digunakan dengan keaadaan mesin masih running memproduksi part lot berjalan, sehingga operator tidak perlu kembali ke mesin terbelih dahulu. Pada aktivitas memnyimpan kembali alat bantu tool dan fixture yang sebelumnya ditempatkan pada terakhir pada saat proses running part product pertama. Berdasarkan pengolahan data aktivitas yang 
sebelumnya 29 menjadi 25 aktivitas dan waktu yang dibutuhkan untuk set-up mesin CNC yang pada awalnya selama 51,050 menit menjadi lebih cepat yaitu dengan total 50,983 menit dengan rincian 44,3 menit internal set-up dan 6,683 menit eksternal set-up, sehingga dengan menggunakan metode $S M E D$ dapat menghemat waktu set-up mesin selama 6,75 menit.

Berdasarkan pengolahan data aktivitas yang sebelumnya 29 menjadi 25 aktivitas dan waktu yang dibutuhkan untuk set-up mesin CNC yang pada awalnya selama 51,00 menit menjadi lebih cepat yaitu dengan total 50,983 menit dengan rincian 44,3 menit internal set-up dan 6,683 menit eksternal set-up, sehingga dengan menggunakan metode SMED dapat menghemat waktu selama 6,75 menit.

Improvment yang dilakukan tidak hanya memikirkan faktor-faktor pemishan antara internal set-up menjadi external set-up saja tetapi juga harus memperhatikan faktor lain. Faktor yang dapat lebih mempercepat waktu set-up dengan merubah program $C N C$, mempercepat gerakan tanpa pemakaian mesin, mempercepat feeding dan menggunakan alat bantu yang dapat digunakan untuk mempersingkat waktu set-up mesin $C N C$ yang dilakukan.

Pada penerapan SMED kegiatan set-up mesin CNC Turning pada pembuatan produk komponen sparepart aerospacae dapat dilakukan padaa saat mesin sedang running process. Frekuensi set-up dalam setiap mesin berbeda-beda sesuai dengan bentuk dan desain part yang akan diproduksi pada mesin tersebut. Dikarenakan terdapat beberapa part yang tidak bisa melakukan set-up pada keadaan mesin masih running process karena dikhawatirkan saat running process terdapat trouble yang dikarenakan bentuk desian part tersebut yang kompleks. Penerapan SMED yang dilakukan perusahaan X yang memproduksi sparepart aerospace dapat meningkatkan produktivitas pada mesin CNC Turning khususnya pada departemen produksi Cell $\mathrm{A}+\mathrm{B}$ dari perusahaan $\mathrm{X}$ dan tentu saja akan meningkatkan provit yang lebih besar bagi perusahaan $\mathrm{X}$ dari periode sebelumnya.

\section{KESIMPULAN DAN SARAN}

\section{V.1 KESIMPULAN}

Penerapan SMED pada Perusahaan $\mathrm{X}$ dapat meningkatkan produktifitas produksi sparepart aerospace dan provit perusahaan. Aktivitas set-up awal sebelum dilakukan penerapan $S M E D$ sebanyak 29 aktivitas, Setelah dilakukan perbaikan dengan menggunakan metode SMED dari set-up mesin maka selanjutnya terdapat beberapa aktivitas yang digabungkan, dikurangi dan dipindahkan urutannya. Aktivitas set-up setelah dilakukan improvement yang dilakukan pada mesin CNC Turning menjadi 25 aktivitas saat melakukan set-up mesin dan waktu yang dibutuhkan untuk set-up mesin CNC Turning yang pada awalnya selama 51,050 menit dengan penerapan metode SMED menjadi lebih cepat yaitu dengan total 50,983 menit dengan rincian 44,3 menit internal setup dan 6,683 menit eksternal set-up, sehingga dengan menggunakan metode $S M E D$ dapat menghemat waktu set-up mesin selama 6,75 menit.

\section{V.2 SARAN}

Saran untuk PT. X, hasil optimalisasi waktu menggunakan metode Single Minutes Exchange of Dies (SMED) dapat diterapkan juga pada mesin-mesin produksi lainnya guna meningkatkan efektivitas dan efisiensi pekerjaan sehingga produktivitas dapat meningkat.

Saran untuk peneliti selanjutnya adalah dalam melakukan Improvement tidak hanya memikirkan dari faktor-faktor pemisahan antara internal set-up menjadi eksternal set-up saja tetapi juga harus memperhatikan faktor lain. Fakor yang dapat lebih mempercepat waktu set-up dengan merubah program CNC, mempercepat gerakan tanpa pemakanan mesin, mempercepat feeding dan menggunakan alat bantu yang dapat digunakan untuk mempersingkat waktu set-up mesin $C N C$ yang dilakukan.

\section{REFERENSI}

Adanna, I. W., dan Shantharam, A. 2014 Improvement of set-up time and production output with the use of single minute exchange of die principles (SMED).International Journal of Engineering Research. 2014; 2 (4): 274-277

Arief F.N . 2017. Perbaikan Waktu set-Up Dengan Menggunakan Metode Smedpada Mesinfilling Krim. Operations Excellence Vol.9, No.3, pp 214.

Goubergen. DV, H.V Landeghem, and H Sheral. 2004. A Quantitative Approach for Set-up

Muhammad Faizal Nurrizky, Muhammad Anwar Septiana, Jamari Machmudin, Muhamad Syafii 
Reduction of Machine Lines. IIE Annual Conference.

Ohno, T. 1998. Toyota Production System: Beyond Large-Scale Production. CambridgePress, Norwalk.

Saputra, R., Arianto, H., \& Irianti, L. 2016. Usulan Meminimasi Waktu Set-Up dengan Menggunakan Metode Single Minute Excghange Die (SMED) di Perusahaan X, pp. 4. 2016.

Suhardi, B., Satwikaningrum, D. (2015). Perbaikan Waktu Set-Up dengan menggunakan metode SMED.

Sharma, K., Nithesh, N., Prabu, A., Varghese, G. (2014). Set-up Time Reduction for CNC Hobbing Machine Implementing SMED and Design Of "Split Fixture"

Shongo, S. (1985). A Revolution in Manufacturing: The SMED System. Productivity Press. USA. And Other Process Improvement Tools Aplication: an Improvement Ptoject of 5-axis CNC Machine

Sivakumar, M., Balasubramani, T., \& Stany , M. C. 2015. Lean manufacturing in carriage building press shop using by SMED and VSM tools. International Journal of Innovations in Engineering and Technology (IJIET), 2015; 5: 235-241 